\title{
The Relevance Of The Environmental Factor In Corporate Strategies: An Application To The Consumer Goods Industry
}

\author{
Rafael Bravo Gil, (Email: rbravo@unizar.es), University of Zaragoza, Spain ${ }^{(1)}$ \\ Elena Fraj Andrés, (Email: efraj@unizar.es), University of Zaragoza, Spain \\ Eva Martínez Salinas, (Email: emartine@unizar.es), University of Zaragoza, Spain
}

\begin{abstract}
Over the last few years companies have begun to consider the environmental factor in their corporate and marketing strategic decisions. In this context, the purpose of this study is to analyse the main pressure factors of this new business philosophy. Consequently, the concept of "Corporate Environmentalism" (Banerjee, 2002) has been introduced and a model of environmental orientation and strategy is proposed. The information has been obtained from 81 personal interviews with companies that belong to the consumer goods industry. A structural equation modelling methodology has been conducted. Results show that competitive advantages and the management environmental commitment are the firm's main eco-orientation determinants. The consumer goods sector is aware of their environmental responsibility, but this factor is not a priority in their decision-making process.
\end{abstract}

\section{INTRODUCTION}

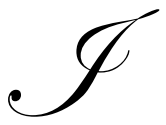

$\mathrm{n}$ the last few years the environmental factor has been incorporated into the firms' global management, mainly as a result of the considerable relevance attached to social pressure, environmental legislation and competitive advantage generated by such incorporation. These circumstances are changing the competitive scene, posing new challenges and opportunities, and promoting the adoption of new environmentally friendly technologies (Del Brío et al., 2001).

Firms feel obliged to comply with the existing legislation on environmental issues and satisfy the new demands from consumers who require more serious concern for sustainable development. Besides, they are the main consumers and transformers of environmental resources, as well as a major source of pollution and waste (Claver and Molina, 2000).

In this context, very varied research on environmental issues is being conducted. Some works analyse the ecological consumer behaviour (Kaiser and Wilson, 2000; Laroche et al., 2001; Fraj and Martínez, 2004), others analyse corporate environmental management (Claver and Molina, 2000; Del Brío et al., 2001; González and González, 2005, Antón et al., 2004; Cole et al., 2005) and finally a series of works study the importance attached to the environmental factor and its influence on corporate and marketing strategic decisions (Ottman, 1995; Sheth and Parvatiyar, 1997; Bañegil and Rivero,1998; Rivera and De Juan, 2000; Banerjee et al., 2003; Bjørner et al., 2004).

The latter approach will be the focus of our study. Specifically, our interest is to analyse the influence of social pressure, environmental legislation, competitive advantage and management commitment on the firm's environmental orientation and strategy development. Consequently, we will turn to the concept of "Corporate Environmentalism" following the research line developed by Banerjee (2002) and Banerjee et al. (2003). The study will be focused on the consumer goods industry. 
Special emphasis will be laid on corporate and marketing strategies in order to find the degree of integration of the environmental factor in the strategic planning process of firms and how this integration is reflected in the marketing mix decision-making.

Our paper is structured as follows. First, the concept of "Corporate Environmentalism" and its antecedents in the literature will be thoroughly analysed. This will be the basis of the conceptual model and the hypotheses proposed. Then, the methodology used will be explained. Thirdly, we will present the result analysis. Finally, the main conclusions and implications of our study will be developed.

\section{LITERATURE REVIEW}

In this section we present a review of the main works we have used for our study. First, we introduce the concept of "Corporate Environmentalism" and its antecedents or pressure factors. Next, on the basis of this literature, we establish the hypotheses on the proposed conceptual model.

\section{The Concept Of "Corporate Environmentalism" And Its Antecedents}

Banerjee (2002) introduces the concept of "Corporate Environmentalism" as "the organization-wide recognition of the legitimacy and importance of the biophysical environment in the formulation of organization strategy, and the integration of environmental issues into the strategic planning process".

The firm's strategic planning process undergoes a change when environmental issues are taken into consideration. It is thus important to identify two planning-related aspects emerging in the literature: corporate environmental orientation and business strategy.

The first concept refers to the firm's responsibility towards the environment, the recognition of the impact of their economic activity on nature and the need to minimize such impact. It is a new philosophy reflected in the firm's internal and external areas. On the one hand, the focus is on values, ethical behaviour and the commitment to environmental protection. On the other hand, there is a need to meet the stakeholders' goals through environmental protection, sustainable development and the projection of a positive public image to maintain the firm's reputation. In this respect, the number of firms that follow the principles of Corporate Social Responsibility is growing steadily, and one of the reasons is that the customers' perception is different if the firms develop their activity with or without a commitment to those principles (Bigné et al., 2005).

The second concept refers to the degree of integration of environmental issues into the strategic planning process. New product development, plant location, research and development investments, new technology development and the changes in product and process design are instances of corporate strategic elements under the influence of environmental issues. Besides, product-market decisions are also conditioned by those issues. In this respect, and as a result of the firm's environmental interest, they may consider the possibility of targeting the environmentally conscious consumer segment and developing new greener products. These types of decisions would be part of the firm's environmental marketing strategies defined by Menon and Menon (1997) as "the concept that reflects a firm's orientation and commitment to the environment".

Regarding the antecedents of the "Corporate Environmentalism" strategy, González and González (2005) argue that the light advances in some areas are mainly due to the pressure exerted on them. Banerjee et al. (2003) gather several antecedents with a direct influence on the firms' performance, and an indirect one through management commitment. This author proposes three antecedents of environmentalism: social concern; regulatory forces; and the possibility of gaining competitive advantage. Furthermore, he proposes a fourth element with a direct and moderating effect on the other variables: management commitment. Finally, the firm's size and type apply a moderating effect between those factors and managerial behaviour.

Social concern is a two-sense antecedent. On the one hand, consumers may demand environmentally friendly products. On the other hand, activists, non-profit organisations, etc. may influence the firm's strategies and 
orientation. Thus, Del Brío and Junquera (2001) reveal that one of the key environmental factors for the environmental behaviour in firms is market demand.

The second antecedent encompasses regulatory forces. Menon et al. (1999) propose the positive effect that political and institutional pressure may exert on the adoption of environmental marketing actions. Furthermore, regulatory forces are an antecedent of "Corporate Environmentalism" because they condition decisions related to packaging, product formulation and distribution channels. Del Brío and Junquera (2001), Del Brío et al. (2001) and Murillo et al. (2004) identify the role of government agencies and legislation as a factor to stimulate environmental behaviour.

Thirdly, the possibility of obtaining competitive advantage is seen as an extremely important economic force that, both internal and externally, influences this concept. In this sense, according to Porter and Van der Linde (1995), caring for the environment may provide a competitive advantage via costs. Moreover, the identification of those consumers more sensitive to environmentally friendly products or services may also generate competitive advantage. Giménez et al. (2002) argue that the introduction of environmental management gives the firm an advance in its competitive position by improving its corporate image and optimising its resources.

The role of top management is also a key factor when adopting a more respectful attitude to the environment (Aragón et al., 2004). Avella et al. (2001) conclude that the management's attitude towards innovation and development of environmentally friendly products is highly relevant for success. This variable affects the concept of "Corporate Environmentalism", moderating the effect that social concern, regulatory forces and competitive advantage have on orientation and environmental strategies (Banerjee et al., 2003).

Finally, both the size and the industry type of the firm influence orientation and environmental strategies (Lanjouw and Mody, 1996; Banerjee et al., 2003). Therefore, large firms tend to present a better environmental attitude since their pollution rates are higher. Besides, firms operating in high pollution sectors also consider this factor as a result of a higher social and legislative pressure.

\section{Conceptual Model And Hypotheses}

In this conceptual framework, it is important to find the factors that lead a firm to consider the environment in its activities. In this case, it is advisable to know the environmental agents participating in these matters and the relationships between them.

The conceptual model of "Corporate Environmentalism" displayed in figure 1 includes the four concepts that integrate such strategy: social concern, regulatory forces, competitive advantage and management commitment, as its antecedents. The political and economic forces involved in the managerial decision-making process are depicted in that figure. Social concern and environmental regulations can be considered as external political forces. The external economic forces would be the added costs generated by non-compliance with the legislation and the idea of following an environmental strategy in order to gain some competitive advantage. The production of new environmentally friendly products and the competitive advantage generated can be considered as one of the main internal economic forces. Finally, the firm's management is seen as an internal political force that boosts and moderates the firm's environmental initiatives.

As this model is based on the one proposed by Banerjee et al. (2003), the hypotheses will be established according to the order in his work. We will first present a set of hypotheses referring to the antecedents of "Corporate Environmentalism" and then the influence of those factors on the antecedent of "Management Commitment". 
Figure 1 - "Corporate Environmentalism": Conceptual Model

Source: Based on Banerjee et al. (2003).

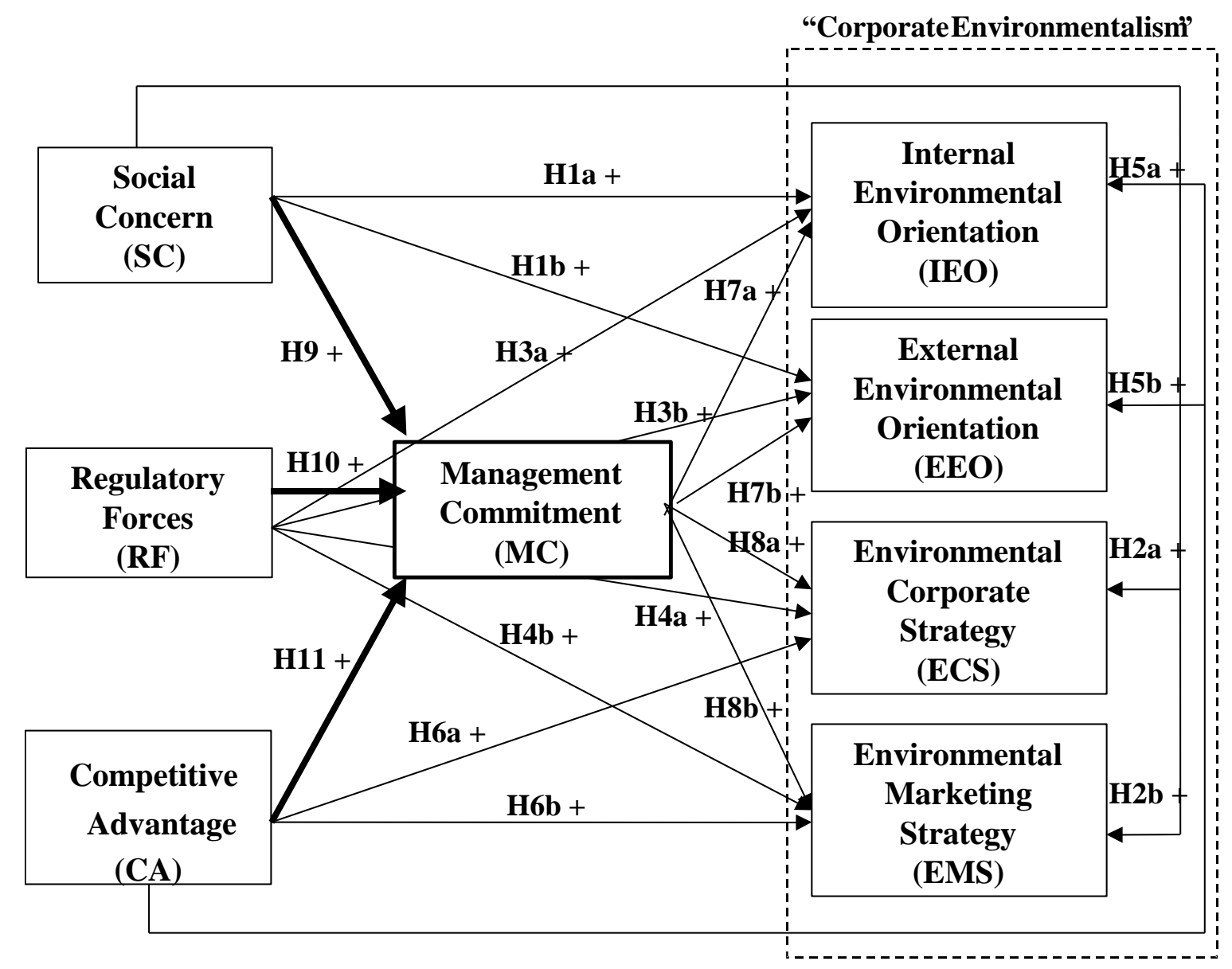

With respect to social concern, Lampe and Gazda (1995) present social and institutional pressure as one of the major forces that encourages the firm's investors and staff to demand the adoption of environmental measures. In this respect, Vicente and Ruiz (2002) state that the importance attached to the environment by environmental and consumer groups is a key factor in the incorporation of environmental issues into managerial decisions. Banerjee et al. (2003) argue that the social pressure from those groups may have a double influence on the firm's environmental orientation and strategies: first, by showing an environmentally friendly image that expresses their responsibility towards this social agent; and second, by developing environmental strategies aimed at the environmentally friendly consumer sector. Furthermore, according to Nieto and Fernández (2004) the firm will attempt to satisfy the expectations of their interest groups by modifying the demand in the goods market. Anton et al. (2004) conclude that the consumers' pressure is highly effective in considering and adopting environmental management systems.

According to these results, we expect this force to influence the orientation and design of environmental strategies, and thus we formulate the first set of hypotheses:

H1a: Social concern will be positively related to the firm's internal environmental orientation.

H1b: Social concern will be positively related to the firm's external environmental orientation.

H2a: Social concern will be positively related to the firm's environmental corporate orientation.

H2b: Social concern will be positively related to the firm's environmental marketing orientation. 
Regulatory forces are the second antecedent under consideration. According to Lampe and Gazda (1995), the growing political power in environmental issues has resulted in the development of a vast environmental legislation covering several fields and affecting all the areas (political, economic and social). These authors also argue that most of these laws need the help from firms to protect the environment, thus it may be an excellent opportunity for environmental marketing. The Entorno Foundation (2001) and (2003) reports that the existence of relatively strict regulations is the main driving force for environmental actions. In this respect, Vicente and Ruiz (2002) conclude that the development of legislation and environmental policies is one of the factors that have contributed to increase the relevance of the environmental variable in managerial decisions. Nieto and Fernández (2004) state that firms will try to meet the expectations of interest groups expressed through regulatory pressure. Later, Cole et al. (2005) prove that environmental regulations are key for the remarkable reduction of pollution levels in the manufacturing sector. Montaño and Chavarría (2005) find that the firm's involvement in environmental actions is mainly due to environmental legislation and regulations.

Therefore, environmental regulations appear to be a relevant pressure factor for companies to consider environmental issues in their environmental orientation and strategies. Accordingly, we establish the following hypotheses:

H3a: Regulatory forces will be positively related to the firm's internal environmental orientation.

H3b: Regulatory forces will be positively related to the firm's external environmental orientation.

H4a: Regulatory forces will be positively related to the firm's environmental corporate orientation.

H4b: Regulatory forces will be positively related to the firm's environmental marketing orientation.

With respect to competitive advantage, we have concluded it is a major economic force that influences the "Corporate Environmentalism" strategy. Some authors found a clear relationship between this antecedent and firms' environmental behaviour. Thus, Ottman (1995) states that firms that target the environmental consumer sector may take advantage of being the first to offer more environmentally friendly products. Proto and Supino (1999) argue that the quality of the environmental information offered by firms about their activity may be their main source of competitive advantage when attempting to gain their customers' loyalty. Besides, Claver and Molina (2000) and Calomarde (2000) state that the cost savings generated by reducing the use of raw materials and energy, improving the production process, etc. may become an important competitive advantage for firms. Recently, Tien et al. (2005) have concluded that the level of implementation of environmental design has a positive effect on the two dimensions of competitive advantage: cost reduction and product differentiation.

Accordingly, our study will establish a direct positive relationship between competitive advantage and the firm's environmental orientation and strategy, formulating the following hypotheses:

H5a: Competitive advantage will be positively related to the firm's internal environmental orientation.

H5b: Competitive advantage will be positively related to the firm's external environmental orientation.

H6a: Competitive advantage will be positively related to the firm's environmental corporate orientation.

H6b: Competitive advantage will be positively related to the firm's environmental marketing orientation.

Regarding management commitment, Drumwright (1994) states this is a very strong internal political force. Top management demonstrates its commitment to environmentalism by appointing senior managers responsible for overseeing the firm's environmental orientation and strategies. In this respect, Del Brío and Junquera (2001), whose work analyses the management awareness influence on the firm's environmental actions, confirmed that the management's attitude evolves in parallel with the opportunities that the environmental management of the firm may generate. Avella et al. (2001) also emphasises the role of top management in the launching of new environmentally friendly products given their great ability to recognise environmental opportunities. Aragón et al. (2004) found that those firms with one or more managers responsible for environmental issues reached higher levels of commitment than those firms where this responsibility was not considered.

According to the literature revised, we propose the following hypotheses that establish a direct positive relationship between management commitment and the four dimensions of "Corporate Environmentalism": 
H7a: Management commitment will be positively related to the firm's internal environmental orientation.

H7b: Management commitment will be positively related to the firm's external environmental orientation.

H8a: Management commitment will be positively related to the firm's environmental corporate orientation.

H8b: Management commitment will be positively related to the firm's environmental marketing orientation.

Finally, some authors argue that the firms operating in polluting industry sectors face a higher social pressure because the consumer perceives they generate more environmental problems (Peretz et al., 1997). Therefore, we consider that the effect of social concern on management commitment will be higher for these types of industries. Milne et al. (1996) concluded that if legislators wanted to exert a real influence on the firms' strategies, they had to negotiate with the firms' management On the other hand, the possibility of gaining competitive advantage in costs or product differentiation will also increase management commitment (Song and Parry, 1997). Banerjee et al. (2003) find that the way firms perceive the pressure of social concern and competitive advantage has a significant influence on their management. According to these results, the following hypotheses establish direct positive relationships between social concern, regulatory forces, competitive advantage and the firm's management commitment:

H9: Social concern will positively influence management commitment to the environment.

H10: Regulatory forces will positively influence the management commitment to the environment.

H11: Competitive advantage will positively influence the management commitment to the environment.

\section{METHODOLOGY}

\section{Data Collection}

Considering our objectives, we conducted a personal survey of consumer goods firms that belonged to the Autonomous Community of Aragón in Spain. This survey was aimed at a manager with some responsibility in environmental and/or marketing issues.

The target population of our study is formed by firms that produce final consumer goods in that Community, registered in the Official Chamber of Commerce and Industry. We also decided to restrict the target population by establishing the condition of having more than twenty employees since these types of firms are more likely to consider the environmental factor in their strategies and they are also more likely to have a marketing and/or environmental department (Foundation Entorno, 2001; 2003).

The fact that these firms make consumer goods, guarantees they are worried about developing commercial strategies addressed to consumers. This population enables us to study our objectives and analyse to what extent firms have considered the environmental factor in their decision making process. As there were not many firms that comply to our study restrictions, we decided to get the information by personal interviews.

\section{Sample Description}

As described in table 1, the initial target population was formed by 152 firms. However, after a detailed analysis of our database we found that three firms were registered with a double activity and twenty had closed down or were involved in a different activity. Therefore, the final target population consisted of 129 firms. The resulting sample that answered the survey was 81 firms, which means a final answer rate of nearly $63 \%$, a remarkably high rate for this type of study. Given the difficulty to arrange an appointment, some firms offered to answer the survey by mail.

The questionnaire was divided into two clearly differentiated parts. The first one collected information about the firm's environmental situation. The second part looked into the firm's corporate environmental responsibility and the consideration of the environmental factor in their products marketing strategies. According to the goals of our study, we have focused on the data collected in the second part of the survey. 
Table 1 - Target Population And Sample

\begin{tabular}{|c|c|c||}
\hline Initial Target Population & 149 & 20 \\
\hline Closed firms /out of our objective & 129 & $100 \%$ \\
\hline Final Target Population & 23 & $17,8 \%$ \\
\hline Firms which collaborate & 25 & $19,4 \%$ \\
\hline Not answered Post-questionnaires & 13 & $10,1 \%$ \\
\hline Answered Post-questionnaires & 68 & $52,7 \%$ \\
\hline Personal questionnaires & 81 & $62,8 \%$ \\
\hline Final Sample & 81 & 20 \\
\hline
\end{tabular}

If we compare the percentage distribution of firms according to macro-sectors and provinces, there is proportionality between the target population and the final sample (table 2). Thus, the sample includes firms from different activity macro-sectors. Textile and footwear are the most common (30\%), followed by food (21\%), wood and paper $(20 \%)$, and household products $(18.5 \%)$.

Table 2 - Target Population And Sample Description By Macro-Sectors

\begin{tabular}{|c|c|c|c|c||}
\hline \hline \multirow{2}{*}{ Macrosector } & \multicolumn{3}{|c|}{ Final Sample } \\
\cline { 2 - 6 } & $\mathbf{N}^{\mathbf{0}}$ & $\mathbf{\%}$ & $\mathbf{N}^{\mathbf{0}}$ & $\mathbf{\%}$ \\
\hline Food and beverages & 33 & $25,6 \%$ & 17 & $21 \%$ \\
\hline Textile, leather and shoe industry & 40 & $31 \%$ & 21 & $25,9 \%$ \\
\hline Wood and paper & 19 & $14,7 \%$ & 16 & $19,8 \%$ \\
\hline Household goods & 21 & $16,3 \%$ & 15 & $18,5 \%$ \\
\hline Chemistry goods & 5 & $3,9 \%$ & 3 & $3,7 \%$ \\
\hline Transport & 2 & $1,5 \%$ & 2 & $2,5 \%$ \\
\hline Others & 9 & $7 \%$ & 7 & $8,6 \%$ \\
\hline TOTAL & 129 & $100 \%$ & 81 & $100 \%$ \\
\hline
\end{tabular}

With respect to the percentage distribution according to their size, most firms are small and medium-size. Nearly half of them have 20-50 employees (46.9\%) and $23.5 \%$ have 50-100 employees. Finally, $48 \%$ of the total has an environment department/manager, a relevant number given that $47 \%$ are small/medium-size firms. This reveals some degree of involvement or, at least, some concern for these issues.

\section{Measurement Of Variables}

In order to reach the goal of our study, we have considered the scales measuring the concept of "Corporate Environmentalism" and its antecedents. Eight concepts based on those proposed by Banerjee (2002) and later by Banerjee et al. (2003) have been used.

The social concern (SC) scale reflects the responding manager's perception of the importance that the general public and potential customers attach to environmental protection. The regulatory forces (RF) scale refers to the influence of government regulations on strategy and the level of environmental regulation faced by firms. The competitive advantage (CA) scale shows items focused on the firm's investment in research and development, cost savings and growth opportunities in new markets. The management commitment (MC) scale reflects the perception of top management's environmental commitment and their support for environmental initiatives.

Internal environmental orientation (IEO) shows the importance the firm attaches to preserving the environment and diffusing such values throughout the company. External environmental orientation (EEO) relates environmental principles with the firm's stakeholders. To measure environmental corporate strategies (ECS), we included items that assess the degree to which the natural environment was integrated with the firm's strategic 
planning processes. Finally, the environmental marketing strategies (EMS) scale measures the degree to which the firms' product-market decisions were influenced by environmental concerns.

\section{RESULTS}

As we stated above, the aim of our work is to determine the influence of factors such as social concern, regulatory forces, competitive advantage and management commitment on the firms' environmental orientation and specifically on their strategy design. Thus, in this section we describe the validation of the scales. In order to contrast the hypotheses proposed, a structural equation analysis will be conducted with the results obtained.

\section{Validation Of Scales}

To validate the scales some exploratory and confirmatory factor analyses were performed. They enabled us to analyse, first, the reliability and unidimensionality of the scales, and, second, their fit, definitive reliability and validity (Grande and Abascal, 1999; Del Barrio and Luque, 2000).

The degree of reliability of a measurement instrument may be analysed through the internal consistency of each subscale measured by Cronbach's Alpha. Thus, for the eight subscales the initial Cronbach's Alpha analysis produced acceptable results, exceeding the recommended minimum value of 0.7 (Nunnally, 1978), except for the subscale that measures External Environmental Orientation. On the other hand, the item-to-total correlation analysis exceeded in all the cases the minimum 0.3 (Nurosis, 1993).

After the exploratory analyses of the subscales used, those items that did not meet the requirements previously described were excluded. In order to verify if all the subscales in the "Corporate Environmentalism" construct and its antecedents have their own entity, we analysed their dimensionality. The purpose of this analysis was to find out if each subscale measures up to its real concept.. Results from the eight factor analyses conducted using the principal components method and varimax rotation, showed that all the scales maintain the same number of items since the factor loadings of each item on the subscale are above 0.5, which denotes their degree of significance (Hair et al., 1999). Furthermore, both the Kaiser-Meller-Olhin parameters and Barlett sphericity test are within the range of the required values, which justifies the application of this technique. At the end, all the scales were reduced to one factor, which verifies their unidimensionality.

Once the exploratory analyses of the scales were done, we proceed to conduct a confirmatory factor analysis of the model proposed in our work. Thus, we have carried out a structural equation analysis of the initial measurement model, considering the different dimensions obtained in the previous exploratory analysis as input variables. We used EQS 5.7b version for Windows ${ }^{(2)}$ using the robust maximum likelihood (Bentler, 1995) as the data estimation method.

First, we develop a structural equation model which will be improved and redefined by adding modifications according to several criteria (Hair et al., 1999; Del Barrio and Luque, 2000). The new versions of the initial measurement model will emerge from the sequential omission of those indicators that fail to meet the recommendations made by Jöreskog and Sörbom (1993): significance of regression coefficients $(\mathrm{t}>2.58, \mathrm{p}=0.01)$; significant factor loadings $(\lambda>0.5)$; and coefficients with a strong lineal relationship $\left(R^{2}>0.5\right.$ or, at least, the minimum threshold of 0.3) (Hildebrant, 1987; Steenkamp and Van Trijp, 1991; Blesa, 2000).

As well as these recommendations, we will also consider goodness of $\mathrm{fit}^{(3)}$ and the final reliability of the scales through Cronbach's tautological, congeneric and parallel ${ }^{(4)}$ Alpha. Besides, the study of composite reliability ${ }^{(5)}$ and the extracted variance analysis ${ }^{(6)}$ for each factor is included in the final reliability analysis (Del Barrio and Luque, 2000). Finally, we will analyse convergent and discriminant validity.

The measurement model that best reflects the conceptual content of each objective for each variable is the one that maintains the same number of items as in the previous analysis in all the scales, with the exception of "Social concern" and "Regulatory forces". In these scales indicators SC.1, SC.3 and RF.6 have been removed because they fail to reach the minimum $\mathrm{R}^{2}$. The goodness of fit of the final confirmatory analysis after removing SC.1, SC.3 and 
RF.6 shows a substantial improvement with respect to the initial one. Therefore, the removal of these indicators appears to have remarkably favoured the definition of the measurement model. This is due to the improvement of $\chi^{2}$ (from 654 with 406 d.f. to 495.4 with 328 d.f.) and other goodness of fit measurements such as CFI (from 0.865 to 0.901 ) and Robust CFI (from 0.898 to 0.932 ), since they are all above 0.90 in the last stage.

In the final measurement model all the factors have indicators with significant loadings above 0.50 . This confirms their convergent validity: each construct perfectly explains, through its indicators, the concept it represents. Furthermore, each concept defined by each construct is different from the concept represented by the others, as confirmed by discriminant validity. These results are shown in table 3. As well as confirming the scales' convergent and discriminant validity, this table verifies whether the indicators, after depurating the scales, are reliable and suitable (final reliability). Thus, the final results of the scales' reliability are highly satisfactory because most statistical parameters reach the established optimum thresholds; only some of them (RF, EEO) show a borderline composite reliability value and extracted variance analysis. Consequently, we can conclude that the final scales are perfectly adequate since all the parameters in the global model exceed the optimum level.

Table 3 - Final Reliability

\begin{tabular}{|l|c|c|c|c|c|c|c|c|c||}
\hline Final Reliability & SC $*$ & RF & CA & MC & IEO & EEO & ECS & EMS & MODEL \\
\hline Cronbach's alpha & & 0,744 & 0,863 & 0,913 & 0,948 & 0,677 & 0,895 & 0,887 & 0,94 \\
\hline Parallel alpha & & 0,679 & 0,864 & 0,858 & 0,954 & 0,617 & 0,933 & 0,948 & 0,968 \\
\hline Tautological alpha & & 0,685 & 0,811 & 0,85 & 0,899 & 0,659 & 0,849 & 0,795 & 0,97 \\
\hline Congeneric alpha & & 0,683 & 0,808 & 0,847 & 0,898 & 0,653 & 0,847 & 0,793 & 0,969 \\
\hline Composite reliability & & 0,679 & 0,797 & 0,839 & 0,896 & 0,617 & 0,845 & 0,824 & 0,968 \\
\hline Extracted Variance Analysis & & 0,415 & 0,499 & 0,635 & 0,632 & 0,456 & 0,478 & 0,54 & 0,528 \\
\hline
\end{tabular}

Note: SC = Social Concern; RF = Regulatory Forces; CA = Competitive Advantage; MC = Management Commitment; IEO = Internal Environmental Orientation; EEO = External Environmental Orientation; ECS = Environmental Corporate Strategy; EMS = Environmental Marketing Strategy. (*) In this case, the reliability is not worthy because it is an indicator.

\section{Determinants Of The "Corporate Environmentalism" Strategy. Contrast Of Hypotheses.}

A structural equation analysis has been applied to verify whether social concern (SC), regulatory forces (RF), competitive advantage (CA) and management commitment (MC) influence Corporate Environmentalism. In this analysis, the concept of Corporate Environmentalism has been considered as the dependent variable (IEO, EEO, ECS, EMS) and its antecedents as the independent ones. Besides, MC also acts as a dependent variable when analysing the influence of SC, RF and CA on the same concept. This analysis will confirm the hypotheses on the determinants of "Corporate Environmentalism": SC (H1-H4); RF (H5-H8); CA (H9-H12); MC (H13-H16) and the influence of these factors on MC (H17, H18 and H19).

Results of this analysis, commented below, are displayed in table 6. But Prior to the interpretation of these results, it is necessary to mention that the goodness of fit of the structural model indicates that data adjust perfectly to the model because the parameters mentioned above are within the recommended limits.

Regarding the results of analysing the influence of social concern on the four dimensions of Corporate Environmentalism, we observe that the coefficients are not significant, which indicates that this variable determines neither orientation nor the firm's environmental orientation.

This means that the management's perception of the importance attached by society to environmental protection influence neither the firms' internal and external orientation nor the development of corporate and marketing strategies. Therefore, we find no support for those hypotheses predicting that social concern would be positively related to the firm's internal (H1a) and external (H1b) environmental orientation, and its environmental corporate (H2a) and marketing (H2b) strategy. 
Table 4 - Structural Model Parameters

\begin{tabular}{|c|c|c|}
\hline HYPOTHESES & Standardised Factor Loadings (t) & Hypotheses \\
\hline $\mathrm{H} 1 \mathrm{a}(\mathrm{SC}=>\mathrm{IEO})$ & $-0,139(-1,710)$ & \\
\hline $\mathrm{H} 1 \mathrm{~b}(\mathrm{SC}=>\mathrm{EEO})$ & $0,047(0,371)$ & \\
\hline $\mathrm{H} 2 \mathrm{a}(\mathrm{SC}=>\mathrm{ECS})$ & $0,103(1,072)$ & \\
\hline $\mathrm{H} 2 \mathrm{~b} \quad(\mathrm{SC}=>\mathrm{EMS})$ & $0,070(0,625)$ & \\
\hline $\mathrm{H} 3 \mathrm{a}(\mathrm{RF}=>\mathrm{IEO})$ & $0,027(0,353)$ & \\
\hline $\mathrm{H} 3 \mathrm{~b}(\mathrm{RF}=>\mathrm{EEO})$ & $0,078(0,708)$ & \\
\hline $\mathrm{H} 4 \mathrm{a}(\mathrm{RF}=>\mathrm{ECS})$ & $-0,001(-0,010)$ & \\
\hline $\mathrm{H} 4 \mathrm{~b}(\mathrm{RF}=>\mathrm{EMS})$ & $0,212 * * *(1,684)$ & YES \\
\hline $\mathrm{H} 5 \mathrm{a}(\mathrm{CA}=>\mathrm{IEO})$ & $0,186 *(2,938)$ & YES \\
\hline $\mathrm{H} 5 \mathrm{~b}(\mathrm{CA}=>\mathrm{EEO})$ & $0,191 * * *(1,684)$ & YES \\
\hline H6a $(\mathrm{CA}=>\mathrm{ECS})$ & $0,271 *(3,107)$ & YES \\
\hline H6b $(\mathrm{CA}=>\mathrm{EMS})$ & $0,481 *(4,774)$ & YES \\
\hline $\mathrm{H} 7 \mathrm{a}(\mathrm{MC}=>\mathrm{IEO})$ & $0,894 *(7,617)$ & YES \\
\hline $\mathrm{H} 7 \mathrm{~b}(\mathrm{MC}=>\mathrm{EEO})$ & $0,767 *(3,470)$ & YES \\
\hline H8a $(M C=>E C S)$ & $0,748 *(6,785)$ & YES \\
\hline $\mathrm{H} 8 \mathrm{~b}(\mathrm{MC}=>\mathrm{EMS})$ & $0,316^{*}(2,849)$ & YES \\
\hline H9 $(\mathrm{SC}=>\mathrm{MC})$ & $0,576 *(6,903)$ & YES \\
\hline $\mathrm{H} 10(\mathrm{RF}=>\mathrm{MC})$ & $0,147(-0,197)$ & \\
\hline $\mathrm{H} 11(\mathrm{CA}=>\mathrm{MC})$ & $0,122(1,407)$ & \\
\hline Goodness of fit: & \multicolumn{2}{|c|}{$\chi^{2}=529,178 ;$ d.f $=332 ;$ CFI $=0.90 ;$ CFI Robust $=0.910 ;$ RMSEA $=0.08$} \\
\hline
\end{tabular}

Note: * 1\%; ** 5\%; *** $10 \%$.

These results reveal that there is no strong social pressure in the consumer goods sector, probably because these firms are not considered as great polluters by society.

We find a similar pattern when analysing the influence of regulatory forces on Corporate Environmentalism. In this case, all the coefficients are positive (except for the relationship with the corporate environmental strategy), but not significant except for the relation between this variable and environmental marketing strategy (H4b). Thus, the environmental regulations faced by these firms determine neither their orientation nor their environmental corporate strategies.

In this respect, the hypotheses that stated that regulatory forces would be positively related to the firm's internal $(\mathrm{H} 3 \mathrm{a})$ and external $(\mathrm{H} 3 \mathrm{~b})$ environmental orientation and its environmental corporate strategy (H4a), could not be confirmed. Just H4b, which related regulatory forces to environmental marketing strategies, has been corroborated. According to these results, government environmental regulations on this sector are not perceived as very strict, which conditions the firms' commitment to environmental protection.

When analysing the influence of competitive advantage on "Corporate Environmentalism", the results show positive relationships, relatively strong and significant.

Firstly, as for the relationship between competitive advantage and internal environmental orientation, there is an estimated coefficient of 0.186 , indicating that competitive advantage ( $\mathrm{R} \& \mathrm{D}$ investment, cost savings and growth opportunities in new markets) is positively related to the importance attached by the firm to the environment and diffusing these values throughout the company. In this sense, we confirm H5a, hypothesising that competitive advantage would be positive related to the firm's internal environmental orientation.

Secondly, regarding the relationship between competitive advantage and external environmental orientation, the estimated parameter is 0.191 , positive and significant, which means that competitive advantage does imply that 
firms relate environmental principles with their stakeholders. Thus, H5b, which stated that competitive advantage would be positively related to the firm's external environmental orientation, has been confirmed.

Thirdly, the relationship between competitive advantage and environmental corporate strategy shows a positive and significant coefficient of 0.271 . This supports H6a, which predicted that relationship. This means that the competitive advantage to be gained by firms is directly related to a greater integration of the environmental factor into the firm's strategy planning.

Finally, the estimated parameter of 0.481 , generated by the relationship between competitive advantage and environmental marketing strategy, indicates a strong and significant positive relationship between these variables. This confirms H6b, which proposed that competitive advantage would be positively related to the firm's environmental marketing strategy.

Therefore, the variable of competitive advantage is indeed a determinant of the application of Corporate Environmentalism both in internal environmental orientation and the design of corporate and marketing strategies.

Other relationships to contrast were those established between management commitment and Corporate Environmentalism. The results prove there is an intense relationship between that variable and the four dimensions which integrate that concept. Thus, the causal relationship between management commitment and internal environmental orientation showed a strong and significant estimated coefficient of 0.894 . This confirms H7a, which established that this variable was positively related to the firm's internal environmental orientation. Consequently, the influence of the management on the importance attached by the firm to environmental protection and diffusing these values throughout the company is proved to be highly relevant.

The relationship of this variable with external environmental orientation is also positive and significant $(0.767)$. Therefore, H7b, which establishes the direct relationship between this variable and the firm's external environmental orientation, would be clearly confirmed. This result would imply that the management may clearly determine the influence of environmental principles in the firm's financial situation and the relationship with its stakeholders.

Furthermore, the estimated parameters of 0.748 (management commitment - environmental corporate strategy) and 0.316 (management commitment - environmental marketing strategy) are positive and significant, indicating that the variable of management commitment is closely related to the consideration of the environmental factor in the firm's decisions on strategy planning and marketing mix. In this case, those hypotheses that established that management commitment was positively related to environmental corporate (H8a) and marketing (H8b) strategy are verified.

We may conclude that the variable of management commitment is one of the major antecedents of Corporate Environmentalism because it substantially influences its determination. This result reveals the importance of the role played by this figure within managerial decisions. Therefore, the management's awareness of the responsibility towards the environment is essential to reflect this commitment inside and outside the firm.

Finally, we have also verified whether the variables of social concern, regulatory forces and competitive advantage influence management commitment to the environment. The results of these relationships reflect that only social concern acts as a determinant of this variable (0.89). Thus, H9, which established that social concern would positively influence management commitment to the environment, is confirmed.

Nevertheless, as the estimated coefficients of regulatory forces and competitive advantage are not significant, we cannot conclude that they influence management commitment. Thus, H10 and H11 are not confirmed.

In this respect, a firm's management appears to feel more pressure from the importance attached to the environment by the general public and customers than from environmental regulations or the competitive advantage generated by considering the environmental factor in their global activities. 
Furthermore, although some relationships are not significant, they do point in the established direction. These results prove that the main antecedents of Corporate Environmentalism are, on the one hand, the competitive advantage the firm may gain by considering the environmental factor and, on the other hand, the management commitment to the environment. Likewise, social concern will be the main determinant of management commitment to the environment.

\section{CONCLUSIONS AND IMPLICATIONS}

The main aim of this work was to analyse the influence of factors such as social concern, regulatory forces, competitive advantage and management commitment on the application of the Corporate Environmentalism concept. In order to reach this goal, we validated the proposed conceptual model and its antecedents, based on the one suggested by Banerjee et al. (2003), and then applied a structural equation analysis. For it this work has focused on the analysis of the environmental behaviour of final consumer product firms.

The results of the analyses, according to the variables considered, lead us to the following conclusions:

Social concern exerts a clear pressure on the firms' management, though not strong enough to make the effort to spread this interest throughout the company and to their stakeholders and incorporate the environmental factor into the firms' strategy decisions.

Regulatory forces, that is, the pressure from government offices and environmental legislation on the consumer goods sector, is not a clear determinant in the application of the Corporate Environmentalism concept. This result might be explained by the fact that $38 \%$ of the firms consider the legislation on the sector neither very strict nor very flexible. However, it is curious that regulatory forces is positively related to environmental marketing strategies perhaps firms do consider environmental legislation in order to get into new markets, launch new products and communicate its environmental responsibility.

We can deduce from these two findings that clients and regulatory forces are not so strong due to this sector is not very pollutant. Anyway, companies that belong to it should consider environmental factor in their global strategy because consumers take firm's ecological behaviour for granted, so if they wanted to be different from competitors they should offer more added value with their products and services than competitors do. It is important, for example, that products include environmental features such as: reusable, recyclable, durable, high-quality and so on. Besides, although environmental legislation is not so strict, legislators should control its performance. Environmental behaviour is not prevalent in the consumer product industry, maybe due to the low incidence of environmental regulations and the lack of an adequate organisational structure. In this respect, public authorities can exert a major influence on firms to force them into a change in their organisational culture and adopting environmental actions. Thus, governments could support stricter environmental regulations and enhance the reputation of those firms which have already included the environmental factor in their management in order to boost this type of behaviour and foster the introduction of environmental issues in business strategies.

Competitive advantage, which refers to cost savings, $\mathrm{R} \& \mathrm{D}$ investments and growth opportunities in new markets, has proved to be a clear determinant in the application of Corporate Environmentalism strategies. The competitive advantage to be obtained by incorporating the environmental factor into management appears to have an influence mainly on corporate and marketing strategies. This may be the result of the marginal effect of environmental regulations, which makes the influence of competitive advantage on "Corporate Environmentalism" even greater. This result totally agrees with the one obtained by Banerjee et al. (2003).

So, if firms perceive added competitive advantage and economic value in the incorporation of environmental values into their strategies, then they would be more motivated to apply the Corporate Environmentalism concept. In this respect, the advantages of being the first to target the growing environmentally conscious consumer segment may be really considerable. Therefore, firms should design adequate products for these consumers at a reasonable price and using return distribution channels, that is, applying environmental marketing strategies. 
Finally, firm's management commitment is positively related to all the dimensions that integrate the concept of Corporate Environmentalism, and thus, it is its most relevant antecedent. This result is not surprising because it is a managerial figure with a very important role that interacts inside and outside the firm. These findings are consistent with the ones obtained by other authors (Coddington, 1993; Ottman, 1995).

These last results show that the strongest force that influence in the development of Corporate Environmentalism concept within the firm is the management commitment. Top management is the person who can encourage the rest of the direction levels. It is important that firms perceive the influence of pressure factors (consumers, regulations, competitiveness) so that the management identifies the advantages attached to environmental organization and finds the necessary instruments to take certain environmental initiatives (adoption of new less polluting technologies, plant location in areas with a lower impact, launching of less polluting products, environmental communication, etc.).

Concerning the corporate environmentalism four dimensions, findings allow us to say that internal and external environmental orientation are best determined by management commitment than by competitive advantages. Top managers are who take final decisions in the firm, and this is reflected inside and outside of it. It occurs the same with environmental corporate strategy. Nevertheless, environmental marketing strategy is best explained by competitive advantage. About this last dimension, results indicate that management commitment and regulatory forces also determine it. From this, it can be inferred that the marketing role within the firm is really important due to it is a functional strategy that helps to commercialise the firm's final products.

On the whole, because firms are increasingly more aware of their responsibility towards the environment and attach more importance to this factor, public institutions might encourage a deeper involvement of firms through the development of different actions: regular communication about the most common environmental problems in the area where the firm is located; training in environmental management systems; campaigns to raise the firms' awareness; information on the environmental activities of competitors; finding output-markets for the firms' waste materials. Other governmental measurements to be taken could be related to increasing the pressure on firms by supporting programmes for non-profit organisations and other pressure groups; fostering alliances between these organisations so that they promote Corporate Environmentalism; and emphasising the competitive advantage that firms can obtain with this strategy.

Following a global environmental strategy involves the whole organisation, thus this strategy has to be considered in corporate decisions such as location of new plants in areas with a lower environmental impact, R \& D investments to reduce the impact of processes and business activities, or the adoption of environmentally friendly technology. Besides, the firm has to be able to transmit all these actions to customers and stakeholders so that their commitment to the environment may be widely known. This is the responsibility of the marketing or environment department, through advertising campaigns in the media, through their products (labelling) or using return channels as often as possible. Therefore, the global environmental strategy must be materialised in several actions on marketing instruments. However, if firms have no clear environmental orientation they will hardly develop that type of corporate or marketing strategies.

These findings are not limited to academic interests, but can also be useful for governments and social pressure groups since they reveal the expectations that should be generated among top managers in order to disseminate them inside and outside the company and also, to use them in the corporate and marketing strategies. Governments should motivate them to follow environmental issues in every area or section of the company. So, they could develop some policies that help those firms that respected the environment and communicate the results achieved from environmentally friendly competitors. The paper also reveals that competitive advantages are the best corporate environmentalism determinant. If firms know the economic and reputation benefits they can enjoy following some ecological principles, likelihood they will consider the Corporate Environmentalism concept in their orientation and strategies.

The main limits of this study are the sample size and the sector. Therefore, results have to be cautiously interpreted since it is not advisable to extrapolate them to other sectors. Furthermore, if the sample were extended, 
these results would also vary. Thus, we still follow this research line, focusing on other sectors such as industry and services, in order to find out if there are differences between them.

\section{REFERENCES}

1. Anton W. R. Q., Deltas G. and Khanna M. (2004). Incentives For Environmental Self-Regulation And Implications For Environmental Performance, Journal of Environmental Economics and Management, 48, pp. 632-654.

2. Aragón J. A., Matías F. and Senise M. E. (2004). Managerial discretion and corporate commitment to the natural environment, Journal of Business Research, 57, pp. 964-975.

3. Avella L., Del Brio J. A., Junquera B. and Valle S. (2001). Factores de éxito en el proceso de desarrollo de nuevos productos ecológicos: una revisión de la literatura, Revista de Economía y Empresa, XV (42), pp. 931.

4. Banerjee S. B. (2002). Corporate Environmentalism. The Construct and its Measurement, Journal of Business Review, 55, pp. 177-191.

5. Banerjee S. B., Iyer E. S. and Kashyap R. K. (2003). Corporate Environmentalism: Antecedents and Influence of Industry Type, Journal of Marketing, 67, abril, pp. 106-122.

6. Bañegil T. and Rivero P. (1998). ¿Cómo es de verde su marketing?, ESIC MARKET, enero-abril, pp. 97111.

7. Bentler P. M. (1995). EQS Structural Equations Program Manual, $7^{\text {a }}$ Edition, Los Angeles (U.S.A), BMDP Statistical Software, Inc..

8. Bigné E., Chumpitaz R., Andreu L. and Swan V. (2005). Percepción de la responsabilidad social corporativa: un análisis cross-cultural, Universia Business Review, 5, pp. 14-27.

9. Bjørner T. B., Hansen L. G. and Russell C. S. (2004). Environmental Labelling and consumers' choice. An Empirical Analysis of the Effect of the Nordic Swan, Journal of Environmental Economics and Management, 47, pp. 411-434.

10. Blesa A. (2000). Influencia de la Orientación al Mercado del Fabricante en las Relaciones en el Canal de Distribución. Tesis Doctoral. Universidad de Valencia.

11. Calomarde J. V. (2000). Marketing Ecológico. Editorial Pirámide. Madrid.

12. Claver E. and Molina J. F. (2000). Medio ambiente, estrategia empresarial y competitividad, Revista Europea de Dirección y Economía de la Empresa, 9 (1), pp. 119-138.

13. Coddington W. (1993). Environmental Marketing: Positive Strategies for Reaching the Green Consumer. Editorial McGraw-Hill. Washington, D.C.

14. Cole M. A., Elliot R. J. R. and Shimamoto K. (2005). Industrial Characteristics, Environmental Regulations And Air Pollution: An Análisis Of The UK Manufacturing Sector, Journal of Environmental Economics and Management, 50, pp. 121-143.

15. Del Barrio S. and Luque T. (2000). Análisis de ecuaciones estructurales. In T. Luque, Técnicas de Análisis de Datos en Investigación de Mercados, Ediciones Pirámide, Madrid.

16. Del Brio J. A. and Junquera B. (2001). Factores inductores del comportamiento medioambiental en las empresas industriales españolas, Revista de Economía y Empresa, XV (41), pp. 75-96.

17. Del Brio J. A., Fernández E. and Junquera B. (2001). Impulso medioambiental en las industrias españolas. El papel de las Administraciones Públicas, Economía Industrial, 39, p. 153-166.

18. Drumwright M. E. (1994). Socially Responsible Organizational Buying: Environmental Concern as a Noneconomic Buying Criterion, Journal of Marketing, 58 (July), pp. 1-19.

19. Fraj E. and Martínez E. (2004). El comportamiento ecológico de los individuos explicado a través de sus características psicográficas: un estudio empírico, Revista Europea de Dirección y Economía de la Empresa, 13 (3), pp.149-168.

20. Fundación Entorno. (2001) Conclusiones del estudio sobre los Hábitos de Consumo y Medio Ambiente en España 2001. Información obtenida de la página web de la organización: www.fundacion-entorno.org.

21. Fundación Entorno. (2003). Entorno 2003. Informe sobre la gestión ambiental en la empresa española. Avances hacia la Sostenibilidad. Ed.: Fundación Entorno. Madrid.

22. Giménez G., Casadesús M. and Valls J. (2002). Gestión ambiental y competitividad: situación actual en la industria española, ESIC Market, 112, pp. 211-224. 
23. González J. and González O. (2005). Environmental proactivity and business performance: an empirical analysis, OMEGA-The International Journal of Management Science, 33 (1) (February), pp. 1-95.

24. Grande I. and Abascal E. (1999). Fundamentos y Técnicas de Investigación Comercial. $4^{\text {a }}$ Edición. ESIC Editorial. Madrid.

25. Grande I. (2000). A Structural Equation Modelling Approach for Assessing the Dimensions of the Optimum Stimulation Level, Journal of International Consumer Marketing, 12 (3), pp. 7-26.

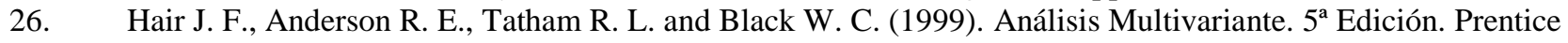
Hall. Madrid.

27. Hildebrandt L. (1987). Consumer Retail Satisfaction in Rural Areas: A Reanalysis of survey data, Journal of Economic Psychology, 8, pp. 19-42.

28. Jöreskog K. G. and Sörbom D. (1993). LISREL 8: Structural Equation Modeling with the SIMPLIS Command Language, Scientific Software International, Chicago. Illinois.

29. Kaiser, F. y Wilson (2000). M. Assessing People's General Ecological Behaviour: A Cross-Cultural Measure, Journal of Applied Social Psychology, 30 (5), pp. 952-978.

30. Lampe M. and Gazda G. M. (1995). Green Marketing in Europe and the United States: an Evolving Business and Society Interface, International Business Review, 4 (3), pp. 295-312.

31. Lanjouw J. O. and Mody A. (1996). Innovation and the International Diffusion of Environmentally Responsive Technology: The Role of Expenditures and Institutions, Research Policy, 25 (June), pp. 549-72.

32. Laroche M., Bergeron J. and Barbaro-Forleo G. (2001). Targeting consumers who are willing to pay more for environmentally friendly products, Journal of Consumer Marketing, 18 (6), pp. 503-520.

33. Menon A. and Menon A. (1997). Environpreneurial Marketing Strategy: The Emergence of Corporate Environmentalism as Market Strategy, Journal of Marketing, 61 (January), pp. 51-67.

34. Menon A., Menon A., Chowdhury J. and Jankovich J. (1999). Evolving Paradigm for Environmental Sensitivity in Marketing Programs: A Synthesis of Theory and Practice, Journal of Marketing Theory and Practice, 7 (2), pp. 1-15.

35. Milne G. R, Iyer E. S. and Gooding-Willians S. (1996). Environmental Organization Alliance Relationships Within and Across Nonprofit, Business, and Government Sectors, Journal of Public Policy \& Marketing, 15, pp. 203-215.

36. Montaño A. and Chavarría C. (2005). La gestión medioambiental en las empresas rurales como estrategia de diferenciación competitiva, Proceedings (CD) of the XIX Nacional Congreso of AEDEM. Vitoria (Spain).

37. Murillo J. L., Garcés C. and Rivera P. (2004). Estrategia empresarial y medio ambiente: opinión de un grupo de expertos, Universia Business Review, 4, Cuarto trimestre, pp. 52-63.

38. Nieto M. and Fernández R. (2004). Responsabilidad Social Corporativa: La última innovación en management, Universia Business Review, 1, pp. 28-39.

39. Nunnally J. C. (1978). Psychometric Theory. McGraw-Hill, $2^{\text {a }}$ Edición, Nueva York.

40. Nurosis M. J. (1993) SPSS. Statistical Data Analysis. SPSS. Inc.

41. Ottman J. A. (1995). Green Marketing. Challenges and Opportunities for the New Marketing Age. NTC Business Books. Chicago. U.S.A.

42. Peretz J. H., Bohm R.and Jasienczyk P. D. (1997). Environmental Policy and the Reduction of Hazardous Waste, Journal of Policy Analysis and Management, 16 (4), pp. 556-574.

43. Porter M. and Van der Linde C. (1995). Green and Competitive: Ending the Stalemate, Harvard Business Review, 73 (5), pp. 120-134.

44. Proto M. and Supino S. (1999). The quality of environmental information: a new tool in achieving customer loyalty, Total Quality Management, 10 (4-5), p. 679-683.

45. Rivera J. and De Juan M. D. (2000). El marketing medioambiental: Un estudio exploratorio sobre su identidad e implementación en las empresas, ESIC MARKET, pp. 471-485.

46. Sheth J.N. and Parvatiyar A. (1997). Ecological Imperatives and the Role of Marketing. In M.J. Polonsky and A.T. Mintu-Wimsatt, Environmental Marketing. Strategies, Practice, Theory and Research. The Haworth Press. Nueva York and London.

47. Song X. M. and Parry M. E. (1997). A Cross-National Comparative Study of New Product Development Processes: Japan and the United States, Journal of Marketing, 61, pp. 1-18.

48. Steenkamp J. B. and Van Trijp H. C. M. (1991). The use of LISREL in the Validating Marketing Constructs, International Journal of Research in Marketing, 8, pp. 283-299. 
49. Tien S.W., Chung Y. C. and Tsai C. H. (2005). An empirical study on the correlation between environmental design implementation and business competitive advantages in Taiwan's industries, Technovation, 25, pp. 783-794.

50. Vicente M. A. and Ruiz M. (2002). Factores determinantes de la integración de la variable medio ambiente en los planteamientos de la economía de la empresa y el marketing, Cuadernos de Gestión, 1 (2), pp. 71-84.

\section{NOTES}

(1) The authors wish to express their gratitude for the financial help received through the following projects: Economic and Social Council of Aragon (CESA); CICYT (SEJ2005-02315), GENERÉS Excellence Group (Ref. S-09) and Multidisciplinar (PM 062/2004); University of Zaragoza and Ibercaja (Ref.: 267-108).

${ }^{(2)}$ We have used the robust maximum likelihood method (Bentler, 1995) for the estimation of the parameters used. We also used the EQS factor scores obtained for each variable.

(3) This study has used the following: measurements of absolute fit that inform about the capacity of the model to predict the correlation or covariance matrix of the observations (Chi-square $\left(\chi^{2}\right)$; the root mean square error of approximation (RMSEA). Measurements of incremental fit that establish comparisons between the estimated model and the void one, where there is no association between any variables (Compared Fit Index (CFI) and Robust Compared Fit Index (CFI Robust)).

(4) If Cronbach's Alpha is denoted as: $\alpha=(\Sigma \mathrm{w} \lambda)^{2} /\left[(\Sigma \mathrm{w} \lambda)^{2}+\left(\Sigma \mathrm{w}^{2} \theta\right)\right]$ where $\lambda=$ the contribution of the ítems to the reliability of the latent variable and $\theta=$ the estimated error of each item. If $w=1$, the model is parallel; if $w=\lambda / \theta^{2}$, it is congeneric; and if $\mathrm{w}=1 / \theta^{2}$, it is tautological (Grande, 2000).

(5) This is the complementary measurement to Cronbach's Alpha that also analyses the construct's internal consistency. It is advisable for this coefficient to be above 0.7 (Hair et al., 1999).

(6) It measures the global variance of the items explained by the latent variable. It is also advisable for this value to be near the threshold of 0.5 (Hair et al., 1999; Del Barrio and Luque, 2000). 